\title{
Hubungan Kemampuan Mengelola Emosi dengan Kecenderungan Berperilaku Agresif Siswa
}

\author{
Mutiara Eka $\mathbf{P}^{\mathbf{1}}$, Herman Nirwana ${ }^{\mathbf{1}}$, Indah Sukmawati ${ }^{\mathbf{1}}$ \\ ${ }^{1}$ Universitas Negeri Padang
}

\begin{abstract}
Abstrak
This research is motivated by the number of students who have a tendency to behave aggressively. One of the factors that is thought to influence is the ability to manage emotions. The purpose of this study is to describe (1) the tendency to behave aggressively, (2) the ability to manage emotions, and (3) test the relationship between the ability to manage emotions and the tendency to behave aggressively in students. The population of the study was 205 students of SMP N 1 X Koto Singkarak in the July-December semester of the 2018/2019 academic year and a sample of 138 students was selected by Stratified Random Sampling. The instrument used is the Aggressive Behavior Trending questionnaire with a reliability of 0.942 and the Emotion Management Ability questionnaire with a reliability of 0.741. Data were analyzed by descriptive techniques and Pearson Product Moment. The research findings are: (1) the tendency of aggressive behavior of students in the high category, (2) the ability to manage students' emotions in the very low category, and (3) there is a significant negative relationship between the ability to manage emotions and the tendency to behave aggressively in students.
\end{abstract}

Keywords: Ability to manage emotions, aggressive behavior

\section{PENDAHULUAN}

Masa remaja merupakan suatu masa atau periode penentu untuk periode dewasa. Dalam periode ini tampak perubahan yang begitu mencolok dan pesat, baik segi fisik maupun psikis, sehingga individu tersebut tidak dapat dikatakan anak-anak, tetapi belum juga dapat dikatakan dewasa (Irianto, Aimon, Nirwana, Prasetia, 2018). Masa remaja adalah masa peralihan dari masa kanak-kanak ke masa dewasa. Pada masa remaja, seorang individu mulai mencoba menemukan jawaban-jawaban yang muncul dalam dirinya (Fitri, Firman, Karneli, 2016). Remaja menemukan jawaban-jawaban itu melalui perubahan besar dalam sikap dan perilakunya (Elhesmi, Neviarni, Ibrahim, 2013). Masa remaja disebut juga sebagai masa transisi, di mana pada masa ini terjadi berbagai perubahan pada dirinya. Perubahan-perubahan tersebut seperti perubahan fisik, emosi, sosial, serta kognitif. Menurut Hurlock (1996:206) "Istilah adolecence, seperti yang dipergunakan saat ini, mempunyai arti yang lebih luas, mencakup kematangan mental, emosional, sosial, fisik”. Hal ini sesuai dengan yang 
dikemukakan Santrock (2007) bahwa masa remaja sebagai periode transisi perkembangan antara masa kanakkanak dengan dewasa yang melibatkan perubahan-perubahan biologis, kogitif, sosio-emosional.

Idealnya seorang remaja yang berkembang dengan baik tidak ada menonjolkan perilaku yang mengarah pada perilaku negatif, sejalan dengan pendapat Prayitno (2006) tingkah laku negatif bukan merupakan perkembangan remaja yang normal, remaja yang berkembang dengan baik akan memperlihatkan perilaku yang positif. Perilaku agresif adalah salah satu perilaku yang mengarah pada perilaku negatif. Remaja yang menampilkan perilaku agresif adalah remaja yang perkembangannya terganggu. Perilaku agresif yaitu suatu tindakan yang dilakukan secara sengaja pada individu lain sehingga mengakibatkan sakit fisik dan psikis pada individu.

Sejalan dengan itu, Buss (dalam Ivancevich, 2007) juga mengemukakan bahwa agresif dapat dikategorikan dalam dimensi fisik, verbal, aktif, pasif, langsung, dan tidak langsung. Bentuk fisik dari agresif dapat melibatkan serangan dengan tinju, mendorong, menampar, menendang, bahkan dengan menggunakan senjata. Bentuk verbal dari agresif ditunjukkan oleh kata-kata, seperti hinaan, makian, gosip, tuduhan, dan lain sebagainya. Agresif aktif menimbulkan bahaya melalui suatu perilaku spesifik, sedangkan agresif pasif dicapai melalui menahan sesuatu yang diinginkan. Bentuk langsung dari agresif adalah ketika orang yang melakukan agresif tersebut yang menimbulkan bahaya, sedangkan dalam agresif tidak langsung orang lain yang menimbulkan bahaya.

Sebagai remaja memiliki kecenderungan untuk berperilaku agresif dangan menjalankan peran sosialnya. Seperti yang dikemukakan oleh Freud (dalam Sobur, 2003:113) bahwa "Id selalu berprinsip untuk memenuhi kesenangan sendiri, termasuk di dalamnya agresivitas". Demikian juga dengan siswa sebagai remaja juga memiliki emosi yang mudah meledak dan tidak terkendali sehingga cenderung menampilkan perilaku agresif dalam menjalankan peran sosialnya. Baron (dalam Sobur, 2003) mengemukakan bahwa agresif adalah tingkah laku individu yang ditujukan untuk melukai atau mencelakakan individu lain yang tidak menginginkan datangnya tingkah laku tersebut.

Berdasarkan penelitian yang dilakukan oleh Ismiati (2015) diketahui bahwa perilaku agresif siswa berada pada kategori sedang. Selanjutnya berdasarkan hasil penelitian Sidaguna (2012) diketahui bahwa perilaku agresif siswa berada pada ketegori cukup tinggi. Dalam penelitian Syahran (2016) hasil penelitian menunjukkan bahwa perilaku agresif siswa berada pada kategori tinggi. Dari penelitian Lestari (2015) diketahui bahwa perilaku agresif yang dimiliki oleh siswa berada pada kategori tinggi. Kemudian, penelitian yang dilakukan oleh Ismail (2014) menunjukkan bahwa agresivitas siswa berada pada kategori sedang. Berdasarkan penelitian terdahulu tersebut dapat disimpulkan bahwa perilaku agresif siswa berada pada kategori sedang.

Menurut Baron \& Byrne (2004:142) "perilaku agresif remaja dipengaruhi oleh beberapa faktor yaitu frustasi, provokasi, agresi yang dipindahkan, kekerasan media, dan keterangsangan yang meningkat di dalam aspek ini dibagi juga menjadi dua yaitu emosi dan kognisi”. Hal ini kecenderungan perilaku agresif pada remaja terjadi karena berbagai faktor yang melatarbelakanginya dan diperoleh remaja saat berinteraksi dengan lingkungannya. Secara umum, remaja memiliki status sebagai siswa SMP dan SMA.

Kecenderungan berperilaku agresif siswa bisa terjadi akibat perubahan ekonomi dan budaya. Hal ini telah membawa dampak yang tidak mengenakan bagi keluarga. Misalnya, ada gejala perubahan cara hidup dan pola hubungan dalam keluarga karena berpisahnya orangtua dan anak dalam waktu yang cukup setiap harinya. Kondisi yang demikian ini menyebabkan komunikasi dan interaksi antara sesama keluarga menjadi kurang intens. Hal ini dapat memicu terjadinya perilaku agresif pada remaja. Sesuai dengan pendapat Clames (dalam Tarmizi, 2009:3) bahwa "terjadinya penyimpangan perilaku anak disebabkan kurangnya ketergantungan antara anak dan orangtua”. Hal ini berdampak pada kedekatan hubungan antar anggota keluarga.

Perilaku agresif dapat menimbulkan kerugian bahkan menyakiti orang lain baik secara fisik maupun psikis. Perilaku agresif dapat terjadi secara verbal maupun fisik, hal ini sesuai dengan yang dijelaskan oleh Berkowitz (dalam Sobur, 2003) agresif adalah segala bentuk tingkah laku yang dimaksudkan untuk menyakiti seseorang, baik fisik maupun psikis. Menurut Berkowitz (dalam Sobur, 2003) yang membedakan agresif sebagai tingkah laku, sebagaimana diindikasikan oleh Baron, dengan agresif sebagai emosi yang bisa mengarah kepada tindakan agresif. 
Dari beberapa pendapat di atas maka dapat disimpulkan bahwa perilaku agresif adalah salah satu bentuk tindakan-tindakan yang bertentangan dengan norma-norma yang berlaku pada masyarakat bisa disebut sebagai perilaku negatif atau anti sosial, yang perlu penanganan khusus agar perilaku negatif atau anti sosial tersebut menjadi perilaku yang positif atau yang bersosial. Perilaku agresif siswa misalnya marah-marah, menghina, mengkutuk, mengkritik, bertengkar, menyindir, menyalahkan dan menertawakan.

Artinya sekolah seharusnya menjadi tempat yang menyenangkan, tempat dimana para siswa dapat mengembangkan berbagai potensi yang dimiliki. Ketika sekolah sudah dicemari dengan perilaku agresif, maka perilaku agresif di sekolah akan semakin meluas. Perilaku agresif yang terjadi dilingkungan sekolah jika tidak segera ditangani dapat mengganggu proses pembelajaran dan perkembangan. Oleh karena itu, perilaku agresif harus cepat ditanggulangi agar tidak merugikan banyak pihak. Dalam hal ini guru BK dapat berperan aktif dalam mencegah dan menangani perilaku agresif tersebut dengan berbagai layanan bimbingan dan konseling (Sriwahyuningsih, Yusuf, Daharnis, 2016).

Remaja ditandai dengan emosi yang mudah meledak dan cenderung tidak dapat mengendalikan emosinya tersebut. Menurut Baron \& Byrne (2004:141) "salah satu faktor yang mempengaruhi perilaku agresif adalah emosi”. Emosi yang merupakan unsur terpenting yang saling berkaitan dan mempengaruhi perilaku agresif. Semakin tinggi mengelola emosi seseorang maka perilaku agresifnya akan semakin rendah. Seperti yang dikemukakan oleh Hurlock (dalam Prayitno, 2006:69) bahwa: "Periode remaja cenderung temperamen atau emosi tinggi, dalam arti emosi negatif mereka lebih mudah muncul. Hal ini disebabkan kerena remaja banyak mengalami masalah dalam memenuhi kebutuhan mereka, kerena lingkungan tidak mendukung, bahkan mengalami usaha pemuasan kebutuhan-kebutuhan itu. Apabila remaja mengalami situasi yang tidak menyenangkan atau mendapat sesuatu yang tidak menyenangkan atau mendapat sesuatu yang tidak disenangi, remaja tersebut lebih cenderung menyelesaikan atau menghadapinya dengan emosi yang negatif bahkan agresif'.

Emosi menurut Walgito (2010) adalah keadaan yang ditimbulkan oleh situasi tertentu (khusus), dan emosi cenderung terjadi dalam kaitannya dengan perilaku yang mengarah (approach) terhadap sesuatu, dan perilaku tersebut pada umumnya disertai adanya ekspresi kejasmanian, sehingga orang lain dapat mengetahui bahwa seseorang sedang mengalami emosi. Menurut James (dalam Sobur, 2003:399) emosi adalah "kecenderungan untuk memiliki perasaan yang khas bila berhadapan dengan objek tertentu dalam lingkunganya. Sedangkan menurut Crow \& Crow (dalam Sobur, 2003) emosi sebagai suatu keadaan yang bergejolak pada diri individu yang berfungsi sebagai inner adjustment (penyesuaian dari dalam) terhadap lingkungan untuk mencapai kesejahteraan individu.

\section{METODE}

Penelitian ini menggunakan pendekatan kuantitatif dengan metode deskriptif korelasional. Populasi penelitian ini siswa kelas VII, VIII, dan IX SMP N 1 X Koto Singkarak T.P 2018-2019 yang berjumlah 205 orang dan sampel sebanyak 138 siswa yang dipilih dengan Stratified Random Sampling. Instrumen yang digunakan pada penelitian ini menggunakan kuesioner. Data dianalisis menggunakan statistik desktiptif dan teknik Pearson Product Moment.

\section{HASIL PENELITIAN}

Berdasarkan pengolahan data yang telah dilakukan, maka data hasil penelitian disajikan dan dianalisis sesuai dengan tujuan penelitian yang diajukan sebelumnya, yaitu (1) mendeskripsikan kecenderungan berperilaku agresif siswa, (2) mendeskripsikan kemampuan mengelola emosi dan (3) menguji hubungan kemampuan mengelola emosi dengan kecenderungan berperilaku agresif siswa.

\section{Kecenderungan Berperilaku Agresif Siswa}

Secara keseluruhan kecenderungan berperilaku agresif siswa SMP N 1 X Koto Singkarak berada pada kategori tinggi dengan persentase $75,69 \%$. Temuan penelitian dapat dipaparkan sebagai berikut.

\section{Kemampuan Mengelola Emosi}

Hasil penelitian menunjukan bahwa pada umumnya kemampuan mengelola emosi berada pada kategori rendah sebesar 34,69\%. Temuan penelitian dapat dipaparkan sebagai berikut. 
Tabel 1. Kecenderungan Berperilaku Agresif Siswa

\begin{tabular}{|c|c|c|c|c|c|c|c|c|c|c|c|c|c|c|}
\hline & \multirow{3}{*}{ Sub Variabel } & \multicolumn{10}{|c|}{ Klasifikasi } & \multirow{2}{*}{\multicolumn{3}{|c|}{ Rata-rata }} \\
\hline & & \multicolumn{2}{|c|}{ ST } & \multicolumn{2}{|c|}{$\mathrm{T}$} & \multicolumn{2}{|c|}{$\mathrm{S}$} & \multicolumn{2}{|c|}{$\mathrm{R}$} & \multicolumn{2}{|c|}{ SR } & & & \\
\hline & & $\mathrm{f}$ & $\%$ & $\mathrm{f}$ & $\%$ & $\mathrm{f}$ & $\%$ & $\mathrm{f}$ & $\%$ & $\mathrm{f}$ & $\%$ & Skor & $\%$ & Kategori \\
\hline 1 & Menyerang Fisik & 14 & 10,14 & 78 & 56,52 & 43 & 31,16 & 3 & 2,17 & 0 & 0 & 71,58 & 71,58 & Tinggi \\
\hline 2 & Menyerang Suatu Objek & 99 & 71,74 & 30 & 21,74 & 5 & 3,62 & 3 & 2,17 & 1 & 0,72 & 26,2 & 87,32 & Sangat Tinggi \\
\hline 3 & Secara Verbal atau Simbolis & 23 & 16,67 & 79 & 57,25 & 35 & 25,36 & 1 & 0,72 & 0 & 0 & 26,94 & 76,98 & Tinggi \\
\hline & Pelanggaran terhadap Hak Milik & 31 & 22,46 & 77 & 55,80 & 24 & 17,39 & 6 & 4,35 & 0 & 0 & 22,87 & 76,23 & Tinggi \\
\hline & Jumlah Keseluruhan & 28 & 20,29 & 88 & 63,77 & 21 & 15,22 & 1 & 0,72 & 0 & 0 & 147,59 & 75,69 & Tinggi \\
\hline
\end{tabular}

Tabel 2. Kemampuan Mengelola Emosi

\begin{tabular}{|c|c|c|c|c|c|c|c|c|c|c|c|c|c|c|}
\hline \multirow[b]{3}{*}{ NO } & \multirow[b]{3}{*}{ Sub Variabel } & \multicolumn{10}{|c|}{ Klasifikasi } & \multirow{2}{*}{\multicolumn{3}{|c|}{ Rata-rata }} \\
\hline & & \multicolumn{2}{|c|}{ ST } & \multicolumn{2}{|c|}{$\mathrm{T}$} & \multicolumn{2}{|c|}{$\mathrm{S}$} & \multicolumn{2}{|c|}{$\mathrm{R}$} & \multicolumn{2}{|c|}{ SR } & & & \\
\hline & & $\mathrm{f}$ & $\%$ & $\mathrm{f}$ & $\%$ & $\mathrm{f}$ & $\%$ & $\mathrm{f}$ & $\%$ & $\mathrm{f}$ & $\%$ & Skor & $\%$ & Kategori \\
\hline 1 & Kejelasan (emotional clarity) & 0 & 0 & 0 & 0 & 19 & 13,04 & 31 & 22,46 & 89 & 64,49 & 8,07 & 32,26 & Sangat Rendah \\
\hline 2 & Intensitas (emotional intensity) & 0 & 0 & 1 & 0,72 & 29 & 21,01 & 22 & 15,94 & 86 & 62,32 & 12 & 34,29 & Sangat Rendah \\
\hline 3 & Perhatian (emotional attention) & 0 & 0 & 0 & 0 & 22 & 15,94 & 34 & 24,64 & 82 & 59,42 & 20,04 & 33,39 & Sangat Rendah \\
\hline 4 & Ekapresi (emotional exspression) & 0 & 0 & 1 & 0,72 & 33 & 23,91 & 20 & 14,49 & 84 & 60,87 & 21,33 & 35,54 & Sangat Rendah \\
\hline & Jumlah Keseluruhan & 0 & 0 & 0 & 0 & 33 & 23,91 & 25 & 18,12 & 80 & 57,97 & 62,44 & 34,69 & Sangat Rendah \\
\hline
\end{tabular}

Hubungan Kemampuan Mengelola Emosi dengan Kecenderungan Berperilaku Agresif Siswa

Selanjutnya dilakukan uji hipotesis. Hipotesis yang diajukan dalam penelitian ini terdapat hubungan yang negatif yang signifikan antara kemampuan mengelola emosi dengan kecenderungan berperilaku agresif siswa.

\section{PEMBAHASAN}

\section{Kecenderungan Berperilku Agresif Siswa}

Berdasarkan hasil analisis data deskriptif, secara keseluruhan kecenderungan berperilaku agresif siswa berada pada kategori tinggi. Hasil tersebut didukung oleh hasil penelitian yang dilakukan oleh Syahran (2016) bahwa perilaku agresif siswa berada pada kategori tinggi. Penelitian Lestari (2015) menunjukkan hasil bahwa perilaku agresif yang dimiliki oleh siswa berada pada kategori tinggi.

Berdasarkan hasil penelitian terdahulu yang telah dikemukakan, dapat memperkuat bahwasanya kecenderungan berperilaku agresif siswa perlu dicegah supaya terciptanya keamanan, ketertiban, dan ketentraman hidup setiap siswa. Koeswara (1988) mengungkapkan bahwa langkah-langkah konkret yang bisa diambil guna mencegah kemunculan atau berkembangnya perilaku agresif dengan cara penanaman moral, pengembangan perilaku nonagresif, serta pengembangan kemampuan memeberikan empati.

Menyerang fisik berada pada kategori tinggi, hal ini dijelaskan oleh Buss (dalam Dayakisni \& Hudaniah, 2009) orang yang mengalami menyerang fisik ini dilakukan dengan cara berhadapan secara langsung dengan individu lain yang menjadi targetnya dan terjadi kontak secara fisik. Menyerang suatu objek berada pada kategori sangat tinggi, menurut Prayitno (2006) ada tiga bentuk perilaku agresif, salah satunya adalah tingkah laku yang merusak lingkungan sekitar seperti mencoret serta menghancurkan benda orang lain. Dalam hal ini yang termasuk ke dalam menyerang suatu objek adalah menyerang benda mati dan binatang (Dayakisni \& Hudaniah, 2009).

Secara verbal dan simbolis berada pada kategori tinggi, menurut Dayakisni \& Hudaniah (2009) tindakan perilaku agresif verbal yang dilakukan oleh individu dengan cara berhadapan secara langsung pada individu. Oleh sebab itu, siswa perlu dibantu oleh guru BK/Konselor untuk mengurangi kecenderungan berperilaku agresif tersebut dengan memberikan layanan informasi tentang komunikasi yang positif, sehingga perilaku agresif sisiwa berkaitan dengan verbal. Pada pelanggaran hak milik berada pada kategori tinggi, menurut Prayitno (2006) yang telah dijelaskan di atas salah satu tingkah lakunya adalah melempari bangunan. Oleh karena itu, siswa perlu dibantu oleh guru BK/Konselor melalui layanan informsi tentang bertanggung jawab dengan yang kita punya.

\section{Kemampuan Mengelola Emosi}

Berdasarkan hasil analisis data deskriptif, secara keseluruhan kemampuan mengelola emosi berada pada kategori sangat rendah dengan persentase $34,69 \%$. Hasil tersebut didukung oleh hasil penelitian yang dilakukan oleh Priatmoko (2011) bahwa mengelola emosi berada pada kategori sedang hingga rendah. Rahayu (2013) menunjukkan hasil bahwa kemampuan mengelola emosi siswa berada pada kategori sedang hingga rendah. 
Berdasarkan hasil penelitian terdahulu yang telah dikemukakan, dapat memperkuat bahwasanya kemampuan mengelola emosi siswa perlu ditingkatkan agar bisa membina diri dalam menghadapi situasi tertentu. Jadi, dapat disimpulkan kemampuan mengelola emosi siswa berperan penting dalam mengurangi kecenderungan berperilaku agresif. Dengan Demikian, guru BK/Konselor diharapkan dapat menyusun berbagai layanan bimbingan dan konseling yang dapat meningkatkan kemampuan mengelola emosi siswa. Penelitian Nadhiroh (2015) mengungkapkan bahwa layanan informasi efektif untuk meningkatkan kemampuan mengelola emosi siswa.

Pada aspek kejelasan (emotional clarity) berada pada kategori sangat rendah, aspek ini berkaitan tentang pengalaman emosi yang berpengaruh pada kebahagiaan seseorang, kesehatan mental, kecemassan dan gaya atribusi (Safaria \& Saputra, 2009). Oleh sebab itu, siswa perlu mengendalikan dan mengelola emosi yang dimilikinya, sehingga mampu untuk menghadapi situasi yang sedang dihadapinya serta kepada guru BK/Konselor dapat memecahkan masalah yang sedang dialami siswa. Aspek intensitas (emotional idensity) berada pada kategori sangat rendah, menurut Safaria \& Saputra (2009) seseorang yang kadang-kadang masih dapat mengontrol keadaan dirinya sehingga emosi yang dialami tidak tercetus keluar dengan perubahan atau tanda-tanda kejasmanian seperti orang yang mengalami ketakutan sehingga jantungnya berdebar-debar.

Pada aspek perhatian (emotional attesion) berada pada kategori sangat rendah, menurut Safaria \& Saputra (2009) dalam hal ini kecenderungan seseorang untuk mampu memahami, menilai, dan menghargai emosi yang sedang dirasakan. Oleh sebab itu, siswa perlu mengembangkan emosi positif sehingga dapat memberikan kesenangan bagi dirinya sendiri, dan untuk guru BK/Konselor bisa memberikan layanan informasi seputar problematika yang ada pada diri siswa. Aspek ekspresi (emotional expression) berada pada kategori sangat rendah, menurut Safaria \& Saputra (2009) emosi yang menampilkan ekspresi umumnya disertai adanya ekspresi kejasmanian sehingga orang lain dapat mengetahui bahwa seseorang sedang mengalami emosi. Misalnya kalau orang yang mengalami ketakutan mukanya akan menjadi pucat, jadi adanya perubahan kejasmanian sebagai rangkaian dari emosi yang dialami oleh individu yang bersangkutan.

\section{Hubungan Kemampuan Mengelola Emosi dengan Kecenderungan Berperilaku Agresif Siswa}

Berdasarkan hasil analisis data deskriptif, secara keseluruhan terdapat hubungan negatif yang signifikan antara kemampuan mengelola emosi dengan kecenderungan berperilaku agresif pada siswa SMP N 1 X Koto Singkarak, dengan koefisien korelasi sebesar -0,345 dan taraf signifikansi 0,000. Artinya, semakin tinggi kemampuan mengelola emosi siswa maka tingkat kecenderungan berperilaku agresif siswa semakin rendah. Sebaliknya, semakin rendah kemampuan mengelola siswa emosi maka tingkat kecenderungan berperilaku agresif siswa semakin tinggi.

Dari hasil penelitian Harejiati (2009) bahwa semakin baik kemampuan mengenali emosi diri dan kemampuan mengelola emosi seseorang maka perilaku belajar yang dibentuk juga akan semakin baik.

Hasil penelitian ini semakin memperkuat teori yang dikemukakan oleh Sobur (2003) saat terbentuknya emosi, ketakutan, agresif, amarah cenderung bercampur, berhubungan dan bukannya terpisah. Menurut Atkinson, Atkinson, dan Hilgard (1983:62) "perasaan badan yang kurang enak (physical discomfort), misalnya juga meningkatkan keterbangkitan emosi dan bisa menimbulkan agresi bila terdapat isyarat untuk memunculkan perilaku agresif'. Keterbangkitan emosional apa pun sumberya, cnderung meningkatkan agresif bila terdapat stimulus yang membangkitkan agresif.

Dayakisni \& Hudaniah (2009:195) mengemukakan "faktor-faktor perilaku agresif yaitu sifat manusia, instink agresif, abnormalitas fisiologis/genetik, dan reaksi emosional terhadap kejadian-kejadian tak menyenangkan (frustasi, marah, ketakutan, dan kesakitan) serta agresi yang dihasilkan dari arousal secara umum dan pengaruh obat-obatan".

Berdasarkan pengujian korelasional maka, ada peluang untuk menurunkan kecenderungan berperilaku agresif dengan meningkatkan kemampuan mengelola emosi siswa. Berikut cara untuk meningkatkan kemampuan mengelola emosi siswa.

Menurut Sobur (2003) Terdapat empat sumber informasi utama yang dapat mengembangkan kemampuan mengelola emosi pada diri individu, antara lain. (1) hadapilah emosi tersebut dengan jalan menghadapi kenyataan yang ditakutkan, (2) jika mungkin, taksirkanlah situasi sebab seseorang membutuhkan orang lain untuk melihat situasi sulit yang dialaminya, (3) kembangkanlah rasa humor dan sikap realistis seperti tertawa dapat meringankan ketegangan emosi, (4) atasilah secara langsung problem-problem yang menjadi sumber emosi memecahkan masalah lebih baik ketimbang mengendalikan emosi yang terkait dengan problem tersebut. 
Disamping itu layanan bimbingan konseling bisa digunakan untuk meningkatkan kemampuan mengelola emosi siswa. Hal ini didukung dengan hasil penelitian yang dilakukan oleh Priatmoko (2011) bahwa layanan bimbingan kelompok efektif untuk meningkatkan kemampuan mengelola emosi. Selanjutnya penelitian yang dilakukan oleh Wahyuni (2015) bahwa layanan bimbingan kelompok dengan teknik cognitive behavior modification mampu meningkatkan kemampuan mengelola emosi. Penelitian Prias (2015) memperlihatkan bahwa layanan konseling individual dengan menggunakan teknik rational emotive behavior therapy supaya dapat meningkatkan kemampuan mengelola emosi. Selanjutnya Irani (2017) bahwa layanan informasi mampu meningkatkan kemampuan mengelola emosi. Di samping itu hasil penelitian Nadhiroh (2015) memperlihatkan bahwa layanan informasi efektif untuk meningkatkan kemampuan mengelola emosi.

Berdasarkan penelitian di atas dapat disimpulkan bahwa layanan bimbingan konseling yang bisa dilakukan oleh guru BK di sekolah untuk meningkatkan kemampuan mengelola emosi adalah layanan informasi, layanan bimbingan kelompok, dan layanan konseling individual.

\section{KESIMPULAN}

Berdasarkan temuan dan pembahasan hasil penelitian, dapat disimpulkan bahwa: (1) kecenderungan berperilaku agresif siswa SMP N 1 X Koto Singkarak berada pada kategori tinggi, (2) kemampuan mengelola emosi siswa SMP N 1 X Koto Singkarak berada pada kategori sangat rendah, (3) terdapat hubungan negatif yang signifikan antara kemampuan mengelola emosi dengan kecenderungan berperilaku agresif siswa SMP N 1 $\mathrm{X}$ Koto Singkarak. Berdasarkan temuan, pembahasan, dan kesimpulan, maka peneliti mengemukakan saran sebagai berikut: (1) guru BK/Konselor, dapat melaksanakan berbagai layanan bimbingan dan konseling untuk meningkatkan kemampuan mengelola emosi siswa seperti layanan informasi, layanan bimbingan kelompok, dan layanan konseling individual. (2) Kepala Sekolah untuk terlaksananya layanan bimbingan dan konseling maka kepala sekolah memberikan jadwal khusus kepada guru BK sesuai jam pelajaran 1 x 40 menit setiap minggunya, agar siswa bisa meningkatkan kemampuan mengelola emosinya.

\section{DAFTAR RUJUKAN}

Atkinson, R. L., Atkinson, R. C., \& Hilgard, E. R. (1983). Pengantar Psikologi Jilid 2, Edisi Kedelapan. Alih Bahasa Nurdjannah Taufiq. Jakarta: Erlangga.

Baron, R. E., \& Byrne. (2004). Psikologi Sosial Jilid 2, Edisi Kedua. Alih Bahasa Ratna Djuwita. Jakarta: Erlangga.

Dayakisni, T \& Hudaniah. (2009). Psikologi Sosial. Malang: UMM Press.

Elhesmi, S., Neviarni, \& Ibrahim, I. (2013). Peran Guru BK dan Guru Mata Pelajaran dalam Mencegah Tawuran Antar Pelajar. Jurnal Konseling. Vol 2, No 3, (7-15).

Fitri, Y. A., Firman., \& Karneli, Y. (2016). Efektivitas Layanan Informasi dengan Pendekatan Role Playing untuk Meningkatkan Penyesuaian Sosial Siswa Kelas VII SMPN 3 Batusangkar. Jurnal Konseling. Vol 1 , No 1, (1-10).

Hajeriati. (2012). Hubuhan Antara Kemamnpuan Mengenali Emosi Diri dan Kemampuan Mengelola Emosi dengan Perilaku Belajar Mahasiswa Jurusan Pendidikan Fisika Fakultas Tarbiyah dan Keguruan UIN Alauddin Makassar. Skripsi. Tidak diterbitkan. Makassar: Fisika FTK UIN Makassar.

Hurlock, E. B. (1996). Psikologi Perkembangan Suatu Pendekatan Sepanjang Rentang Kehidupan. Jakarta: Erlangga.

Irani, L. C. (2017). Pengembangan Panduan Pelatihan Keterampilan Mengelola Emosi sebagai Upaya Preventif Perilaku Bullying Siswa Menengah Pertama. Skripisi. Tidak diterbitkan. Malang: UNM Malang.

Irianto, A., Aimon, H., Nirwana, H., \& Prasetia, T. A. (2018). Komunikasi Interpersonal antara Orangtua dan Anak Remaja serta Identitas Diri Remaja: Studi di Bina Keluarga Remaja Parupuk Tabing, Koto Tangah, Padang. Sumatera Barat. Jurnal Konseling. Vol 26, No 1, (16-25).

Ismail, I. (2014). Hubungan Interaksi Sosial Teman Sebaya dengan Agresivitas Siswa di SMPN 16 Padang. Skripsi. Tidak diterbitkan. Padang: BK FIP UNP.

Ismiati. (2015). Hubungan Kematangan Emosi dengan Perilaku Agresif dan Implikasinya dalam Pelayanan BK. Skripsi. Tidak diterbitkan. Padang: BK FIP UNP.

Ivancevich, J. M., Konopaske, R., \& Matteson, M, T. (2007). Perilaku dan Manajemen Organisasi Jilid 1, Edisi Ketujuh. Alih Bahasa Gina Gania. Jakarta: Erlangga.

Koeswara. (1988). Agresi Manusia. Bandung: Erasa. 
Lestari, T. (2015). Hubungan Antara Kemampuan Pengelolaan Emosi dengan Perilaku Agresif Peserta Didik Kelas VIII SMP Negeri 2 Papar Tahun Pelajaran 2014/2015. Skripsi. Tidak diterbitkan. Kediri: FKIP Kediri.

Nadhiroh, Y. Z. (2015). Pengendalian Emosi. Skripsi. Tidak diterbitkan. Banten: FTK IAIN SMH Banten.

Prayitno, E. (2006). Bahan Ajar Psikologi Perkembangan Remaja. Padang: Angkasa Raya.

Prias, P. H. P. (2015). Pendekatan Naratif dalam Konseling rational Emotive Behavior Therapy (REBT) untuk Mengelola Emosi. Skripsi. Tidak diterbitkan. Yogyakarta: FKIP UNSADA Yogyakarta.

Priatmoko, S. D. (2011). Upaya Meningkatkan Pengendalian Emosi melalui Layanan Bimbingan Kelompok pada Remaja di Panti Asuhan Yayasan Al-Hidayah Desa Desel Sadeng Kecamatan Gunung Pati Semarang. Skripsi. Tidak diterbitkan. Semarang: UNNES Semarang.

Rahayu, R.C. (2013). Deskripsi Kemampuan Siswa Mengelola Emosi pada Kelas IX Sekolah Menengah Kejuruan. Skripsi. Tidak diterbitkan. Pontianak. FKIP UNTAN Pontianak.

Safaria, T., \& Saputra, N. E. (2009). Manajemen Emosi. Yogyakarta: Bumi Aksara.Santrock, J. (2007). Remaja Jilid 1, Edisi Kesebelas. Alih Bahasa Widyasinta. Jakarta: Grafindo Persada.

Santrock, J. (2007). Remaja Jilid 1, Edisi Kesebelas. Alih Bahasa Widyasinta. Jakarta: Grafindo Persada.

Sidaguna. (2012). Upaya Pengurangi Perilaku Agresif Verbal melalui Bimbingan Kelompok. Skripsi. Tidak diterbitkan. Bandung: UPI Bandung.

Sobur, A. (2003). Psikologi Umum. Bandung: Pustaka Setia.

Sriwahyuningsih, V., Yusuf, M. A., \& Daharnis. (2016). Hubungan Prasangka dan Frustasi dengan Perilaku Agresif Remaja. Jurnal Penelitian Pendidikan Indonesia. Vol 2, No 2, (38-51).

Syahran, R. (2016). Upaya Mengurangi Perilaku Agresif Non-Verbald dengan Menggunakan Teknik Role Playing pada Siswa Kelas VIII SMP Negeri 2 Palu. Skripsi. Tidak diterbitkan. Palu: UNTAD Palu.

Tarmizi. (2009). Pola Asuh Orangtua dalam Mengurangkan Perilaku Anak. (Online). http://tarmizi.wordpress.com diakses tanggal 9 Maret 2018 jam 09.00 WIB.

Wahyuni, E. N. (2015). Keefektifan Pendekatan Cognitive Behavior Modification untuk Meningkatkan Kemampuan Mengelola Marah Bagi Remaja. Skripsi. Tidak diterbitkan. Kediri: FKIP Kediri.

Walgito, B. (2010). Pengantar Psikologi Umum. Yogyakarta: Andi. 